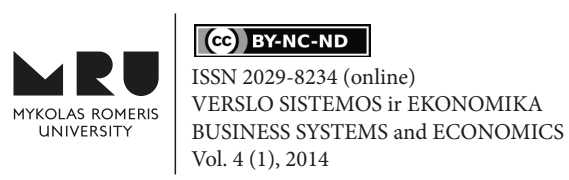

\title{
CORPORATE SOCIAL RESPONSIBILITY IN FOREIGN AND LITHUANIAN CAPITAL COMPANIES
}

\author{
Alfonsas LAURINAVIČIUS \\ Mykolas Romeris University, Institute of Economics and Business \\ Ateities st. 20, LT-08303 Vilnius, Lithuania \\ E-mail: laalfa@mruni.eu \\ Martynas VAIČIULIS \\ Mykolas Romeris University, Institute of Economics and Business \\ Ateities st. 20, LT-08303 Vilnius, Lithuania \\ E-mail: vaiciulis.martynas@gmail.com \\ doi:10.13165/VSE-14-4-1-05
}

\begin{abstract}
This paper is oriented at foreign and Lithuanian capital companies based in Lithuania and the differences between their social responsibility and predominant management types. The research conducted in this paper is based on the public opinion that leads to believing that foreign capital business entities are far more ahead than Lithuanian capital companies as far as corporate social responsibility (CSR) is concerned, and the fact that there is no solid ground to confirm this assumption. The results of the research revealed that the differences do exist, but they are not as vast as the society thinks. It was established that Lithuanian capital companies still lack a fully developed understanding of CSR, meaning that they are still a bit less socially responsible than foreign capital entities, because the idea of CSR is relatively new in the country. Nevertheless, a promising tendency leads to believing that CSR is steadily gaining its significance in the Lithuanian business world.
\end{abstract}

Keywords: corporate social responsibility (CSR), management type, foreign capital, Lithuanian capital, conceptual model.

JEL classification: M14.

\section{Introduction}

Although the idea of corporate social responsibility (CSR) can be traced way back to the ancient civilizations (Blowfield and Frynas, 2006), the concept of modern CSR first appeared in the middle of the 20th century (Carroll and Shabana, 2010). Since then, the interest in the phenomenon has been increasing dramatically, as scholars have been discussing about it academically, businessmen - pragmatically, public figures - politically, etc. (Mitzberg, 1983). However, different approaches to CSR have led to the fact that its percep- 
tion is still highly vague. Despite that, according to the synthesis of formal and informal CSR definitions (EuroVoc, 2013; Government of the Republic of Lithuania, 2010; European Commission, 2011; Waddoc, 2004; Lantos, 2001; Carroll, 1979, 1991, 1999), socially responsible business activities in this paper are understood as voluntary, ethically and economically viable business practices above codified rules, aimed at sustainable development, while striving to mitigate or eliminate social and environmental issues.

Although a slight disagreement exists when it comes to defining CSR, it is clear that a company must be socially responsible; meaning that dilemma of whether "to be or not to $b e$ " has lost its relevance. The key issue today is related to the level of social responsibility of business. It can be said that the minimal level of CSR in a certain place and at a certain time is already predefined. This assumption is made due to the fact that every company must adapt to a macro dimension in order to operate in a certain country or a region (Crane and Matten, 2007; Unerman and O'Dwyer, 2006; Matten and Moon, 2008; Aaronson, 2005; Alas and Rees, 2006; Alas and Sun, 2008; Alas et al., 2006; Davis and Ruhe, 2003; Žitkus and Junevičius, 2007). Companies' maximal level of CSR, on the other hand, has no boundaries. Žitkus and Junevičius (2007), Ubius and Alas (2009), Taras et al. (2011), Mueller et al. (2012) state that it is defined by micro dimensions of business entities directly determined by businessmen, managers and their ethical and moral development. The research conducted by Ubius and Alas (2009) confirmed the fact that CSR depends upon organization's culture which can be categorized into four management types - hierarchic, market, adhocratic and clan - where the biggest differences can be spotted among hierarchic and adhocratic types and between market and clan types.

Due to the ever increasing interest in social responsibility, scholars are constantly striving to determine the way to examine CSR; therefore, a variety of models have been created, giving an opportunity to evaluate the level of social responsibility of a certain company. Maybe one of the best known models so far is Carroll's (1991) pyramid of social responsibility. The essence of it is that CSR comprises four responsibilities related hierarchically, where the priority is given to the bottom ones (economic and legal) as other responsibilities (ethical and philanthropic), which have the most social value, depend upon realization of them. However, the pyramid of CSR was criticized by Schwartz and Carroll (2003) due to its weaknesses. Therefore, the authors modified it and presented a new improved CSR model - three-domain approach - which includes only three elements, i.e. economic, legal and ethical responsibilities. Quite a different approach was chosen by Quazi and O'Brien (2000), who presented a two-dimensional model of CSR. According to it, the extent of social responsibility in a company can be evaluated by its views towards the phenomenon - classical, socioeconomic, philanthropic and modern - which are determined by the degree at which a business entity understands CSR and its outcomes to the company. These views can be linked to a set of responsibilities a business entity is willing to take, i.e., hierarchic and socioeconomic - mostly to economic and legal responsibilities; philanthropic and modern to economic, legal, ethical (and philanthropic, according to the pyramid of CSR).

When it comes to Lithuania, it must be said that the traditions of modern business, including CSR, are just starting to develop. The historical context of the country determined that the possibility to incorporate social responsibility into business practices introduced itself only at the end of the 90s, but the popularity of CSR and overall interest in it has been growing since. Not only business is becoming increasingly aware of its responsibilities towards society and the environment, but, according to Vilkè (2011), scholars are getting more 
and more interested in the topic, as well. Nevertheless, public society of the country still believes that foreign capital companies operating in Lithuania are much more socially responsible than the local capital ones. Arguments to support this statement are usually based on assumptions rather than factual information; therefore, it is not quite clear if Lithuanian capital companies indeed are still far from being socially responsible when comparing them to foreign capital business entities. That is why it would be beneficial to check whether the public opinion is viable and highlight the problematic areas which must be improved in order to increase social responsibility. It must be emphasized that Lithuanian authors Mačys and Vijeikis (2010) in their set of articles under the common title "Does the Social Responsibility Matter?" have already revealed that there is a gap between foreign and Lithuanian companies approach to CSR, however, their research was mainly oriented at financial institutions (e.g., banks, insurance companies, etc.), which in Lithuania are usually of a foreign origin. What is more, although the authors do agree that there is a difference between small, medium and large companies when it comes to social responsibility, but their research lacks a clear differentiation, including this measurement. Finally, Mačys and Vijeikis (2010) state that the research that they conducted is a pilot study, which leads to believing that a substantial need to continue researches in this field exists. Therefore, the main goal of this paper is to evaluate the extent of CSR in foreign and Lithuanian capital medium and large business entities, operating in the Republic of Lithuania, and reveal the differences between these companies.

\section{Methodology of the research}

The research of this paper is based on two-dimensional model of CSR, which was improved by the elements of the pyramid model and the three-domain approach. That means that two aspects of CSR are being investigated: firstly, the overall business entities' understanding of CSR; secondly, their expectations towards the outcomes of socially responsible behavior. What is more, relying on the fact that the actual social responsibility of a business is defined by its micro dimension, the main elements of it have also been incorporated into the model, i.e., culture-management types were linked to certain views towards CSR. In the frame of this research, companies that have the classical view towards CSR are thought to be managed according to hierarchic management type, socioeconomic view - market management type, philanthropic view - clan management type, and modern view - adhocratic management type.

Based on the assumptions made in an introductory part, three hypotheses concerning foreign and Lithuanian capital medium and large enterprises registered in the Republic of Lithuania (hereinafter - companies, business entities, etc.) are being tested:

I. $\boldsymbol{H}_{0}$ : A vast difference exists between the extents of social responsibility in companies.

II. $\boldsymbol{H}_{0}$ : A vast difference exists between the predominant management types in companies.

III. $\boldsymbol{H}_{\boldsymbol{0}}$ : A link exists between the management type and the extent of CSR.

\section{Companies of choice}

Micro and small businesses are not taken into consideration in this research for a few reasons. First of all, this type of companies is usually local businesses; therefore, collection of data would be much more difficult and quite incomparable due to the limited number of foreign capital micro and small companies in the country. Moreover, it is thought that 
medium and large companies are more familiar with the concept of social responsibility as they usually have special policies on CSR and its implementation, meaning that they are able to communicate their social responsibility much clearer. Besides that, the resources of these companies allow them to create special positions or even departments which are responsible for the social responsibility of the business. That at some extent ensures the reliability of the data they provide.

Another important fact to mention is that the research is conducted without orienting it at a certain industry, i.e., the goal is to reveal the overall tendency in Lithuania. It is thought that before carrying out investigation among companies which operate in the frame of certain business activities, it is crucial to be acquainted with the general situation of the country. Therefore, this research can be interpreted as the focus investigation.

\section{Data collection}

In order to collect the data necessary for the research, an expert valuation method was chosen. It is based on the assumption that an expert group, in this case - business entities, have a particular set of knowledge, expertise and a well-developed intuition, all of which can be generalized in their opinions on one or another matter. This type of research method was chosen due to the complexity and vagueness of the concept of CSR. That is why in order to select only experts competent enough for the research, they had to match at least one of the following criteria:

- Publicly declare their CSR (for example, on their website, in annual reports, etc.).

- Integrate standards related to CSR (ISO 26000, SA 8000, etc.) into business practice.

- Acknowledge United Nations Global Compact.

According to the before-mentioned criteria, 250 foreign and Lithuanian capital medium and large companies registered in the Republic of Lithuania were chosen. Despite the fact that one of the advantages of the expert valuation method is that only a small number of experts (5-7) is necessary for the conclusive results, a questionnaire was sent to a lot more respondents in order to eliminate the risk of low feedback. A questionnaire contained 20 statements grouped into three blocks: representing the overall understanding of CSR, the expected outcomes of socially responsible behavior, and the predominant management type. The respondents were asked to classify statements by priority: in the first two blocks from 1 to 6 ; in the third - from 1 to 8 . The highest number means that the statement is the most relevant to their company and vice versa. Experts were also presented with an opportunity to eliminate statements, which do not correspond to their company at all.

\section{Assessment of the reliability of the research data}

As it was expected, the responsiveness of the research's questionnaires was quite low. It only reached $4.8 \%$, meaning that only 12 companies (5 Lithuanian capital and 7 foreign capital) submitted their opinions. This in essence confirms that this research, as most of the researches in the field, is limited to the fact that socially irresponsible companies are not taken into consideration. The latter means that due to the lack of interest of socially irresponsible business entities, their participation in this kind of research is highly doubtful. 
Despite the low responsiveness rate, it is believed that the quantity of answers is sufficient enough due to the aforementioned advantage of the expert valuation method - results can be generated from the small number of experts. Still, in order to see whether the data can be used for the further analysis, it is crucial to assess the unanimity of the experts' opinions. This will also at some extent eliminate the risk that some of the opinions are artificially created in order to form the image of a socially responsible company.

Table 1. Assessment of the reliability of data

\begin{tabular}{|c|c|c|}
\hline \multicolumn{3}{|c|}{ The Extent of CSR } \\
\hline Companies & Lithuanian capital & Foreign capital \\
\hline $\mathrm{W}=$ & 0.84 & 0.902 \\
\hline $\mathrm{W} \times \mathrm{m} \mathrm{x}(\mathrm{k}-1)=$ & 12.6 & 18.943 \\
\hline $\mathrm{Xcrit}^{2}=$ & 11.345 & 11.345 \\
\hline $\mathrm{H}_{0}$ : Experts' opinions do not match & False \\
\hline \multicolumn{2}{|c|}{ Management Type } \\
\hline Companies & Lithuanian capital & Foreign capital \\
\hline $\mathrm{W}=$ & 0.872 & 0.853 \\
\hline $\mathrm{W} \times \mathrm{m} \mathrm{x}^{2}(\mathrm{k}-1)=$ & 13.08 & 17.914 \\
\hline $\mathrm{X}_{\text {crit }}{ }^{2}=$ & 11.345 & 11.345 \\
\hline $\mathrm{H}_{0}$ : Experts' opinions do not match & False \\
\hline
\end{tabular}

Source: Created by the authors

According to the data collected from the experts, Kendall's coefficient of concordance $W$, which is used for determining the statistical significance when there are more than two ranges of variables, was calculated. The bigger the value of this coefficient in the scale of 0 to 1 , the stronger correlation between variables in question exists. Results of the calculations proved that there is almost no difference of opinions concerning the extent of CSR and the predominant management type in companies (see Table 1).

The significance of Kendall's $W$ itself was also tested. The hypothesis $\mathrm{H}_{0}$ stating that experts' opinions do not match was denied, because the statistical value $W \times m \times(k-1)$ (where $\mathrm{m}$ - the number of experts; $\mathrm{k}$ - number of the objects investigated) was bigger than the critical value $X_{c r i t}{ }^{2}$. It was calculated with a significance level $\alpha$ equal to 0.01 , meaning that there is only $1 \%$ chance that the unanimity of experts' opinions is coincidental. The unusually high level of significance was chosen in order to fully mitigate the risk of unreliable data. All things considered, the analysis of experts' opinions unanimity confirmed that the same extents of CSR and management types predominate in companies with similar capital origin and that the results of the research should be reliable.

\section{Results of the research}

The data revealed that, despite of capital nature, all business entities demonstrate equally wide understanding of CSR and associate socially responsible behavior with potential benefits, i.e., they are aware that CSR provides positive returns for the company. Nonetheless, it is worth mentioning than Lithuanian capital business entities have more old-fashioned beliefs, which may limit their social responsibility and sabotage their willing- 
ness to accept CSR. For example, they still at some level see CSR as charitable activity, while foreign capital companies already find this viewpoint almost irrelevant. It is also important to emphasize the fact that despite the nature of the capital, all companies still lack the awareness of their corporate citizenship.

\section{$\boldsymbol{H}_{0}:$ A vast difference exists between the extents of social responsibility in companies.}

The comparative analysis of the extent of social responsibility in companies revealed a few facts. First of all, the extent of social responsibility in both types of companies is quite similar, i.e., business entities understand CSR equally wide and link it with potential benefits for the company. However, differences occur due to the fact that Lithuanian capital companies' views towards CSR are not fully developed yet and still can be quite inconsistent. On the other hand, foreign capital companies have more experience when it comes to CSR, so their views are clearer and more specific. All in all, the differences exist between the extent of social responsibility in foreign and Lithuanian capital companies, but they are not vast; therefore, the first hypothesis cannot be fully confirmed and has to be at least partly denied.

When it comes to the management types, a clear tendency can be spotted in both foreign and Lithuanian capital companies - features of all management types predominate at some extent. However, the highest priority in both types of business entities is given to adhocratic management, which, by the way, is equally high. It must be noted that a high significance of this management type in the light of this research is mainly related to the innovation oriented approaches for conducting a business, e.g., using the most advanced technologies, business practices, etc., which may also include the concept of corporate social responsibility. The differences occur when other management types, which predominate in companies, are compared. Lithuanian capital business entities tend to be more hierarchically structured, while foreign capital companies give a higher priority to formal rules and norms. It correlates well with the fact that foreign capital business entities are more mature when it comes to CSR because these formal rules are usually expressed as codes of conduct, which are useful when spreading the idea of social responsibility among employees and clearly communicating it to the external environment. What is more, it can be said that foreign capital companies have a bit clearer features that are associated with the clan management type. Lithuanian capital companies, on the other hand, tend to give a higher priority to market management, because they express the opinion that profits must be generated at any costs, revealing that economic responsibility might be prioritized a bit too much. That corresponds well to the fact that they also give a high priority to the statement that business has only one goal - to be as profitable as possible.

\section{$\boldsymbol{H}_{0}:$ A vast difference exists between the predominant management types in companies.}

So, it is clear that a mix of different features of all management types predominate in the companies. However, despite the nature of capital, both types of businesses base their management on adhocratic management type platform equally. The differences are spotted only due to the fact that a bit different levels of importance are given to other management types. All of this leads to the conclusion that there is a difference between predominant management type in foreign and Lithuanian capital companies; however, it is not vast, therefore, the second hypothesis must be at least partly denied, as well.

$\boldsymbol{H}_{0}:$ A link exists between the management type and the extent of CSR. 
When it comes to the link between the predominant management type and the extent of CSR in a company, it should be said that it clearly exists, so the third hypothesis must be fully confirmed. The main reason for this is that companies equally see social responsibility as far as a wide understanding of CSR and expected positive outcomes of social responsibility are concerned, which corresponds to the prioritization of adhocratic management in both types of companies, as this management type is related to the modern view of CSR the most. What is more, both foreign and Lithuanian capital business entities tend to incorporate other management types, but their levels of importance are different depending on the capital nature. It can be said that these differences are reflected in the extent of CSR in companies. For example, Lithuanian capital business entities give a high priority to both adhocratic and hierarchic management types, which oppose to each other. The same can be said about the understanding of CSR in these companies, because they still have outdated beliefs, which do not correspond to the communicated wide understanding of CSR. Outdated beliefs can also be linked to the market management type, which is highly prioritized in Lithuanian capital business entities, as well.

According to the results of the research, a map that represents the extent of CSR and predominant management types in business entities was created (see Figure 1). This map also reveals the relation between the extent of CSR and predominant management types in companies.

Figure 1. The map of the extent of CSR and predominant management types

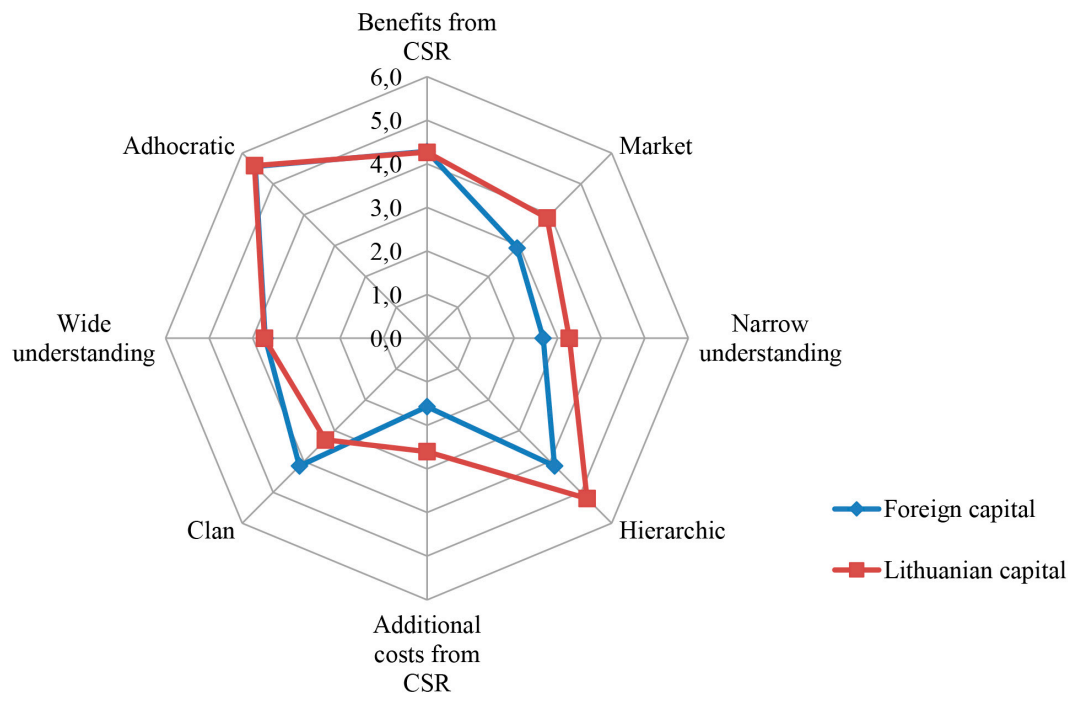

Source: Created by the authors according to the data collected from the business entities

In Figure 1, it can be clearly seen where the differences among foreign and Lithuanian capital companies emerge. According to the characteristics of the management types, they are depicted by the understanding of CSR and the expected outcomes of socially responsible 
behavior. The equal range of the wide understanding of CSR and the expected positive returns from socially responsible behavior in foreign and Lithuanian capital business entities can be linked to the predominant adhocratic management type in these companies. Different importance of other management types in the business entities is reflected in companies' disagreements when it comes to a narrow understanding of CSR and expected outcomes of socially responsible behavior related to additional costs. It was determined that Lithuanian capital business entities have more features of hierarchic and market management types, while foreign capital companies tend to additionally incorporate elements from clan management. It is assumed that due to this reason Lithuanian capital companies still have more beliefs, which are associated with the narrow understanding of CSR and more often tend to consider social responsibility only as additional costs for the company. The differences are quite minimal and may be easily explained by the fact that Lithuanian capital companies have less experience when it comes to CSR and management as a whole. The aforementioned facts can be seen clearer when the influences of the opposing opinions are eliminated (see Figure 2).

Figure 2. Alternative map of the extent of CSR and predominant management types

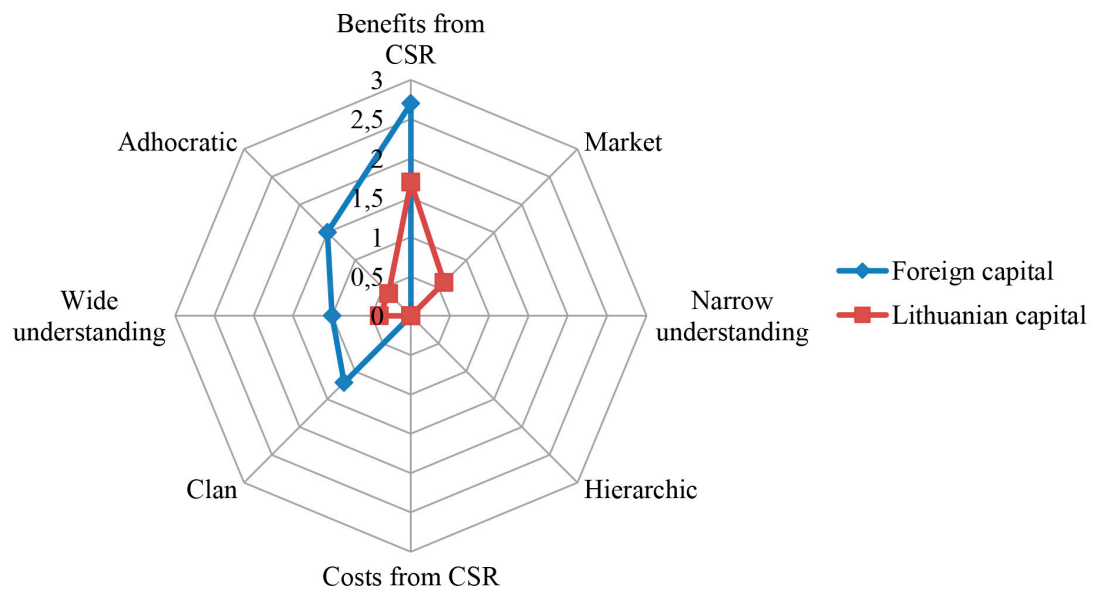

Source: Created by the authors according to the data collected from the business entities

The alternative map of the extent of CSR and predominant management types reveals a more understandable image and confirms the fact that foreign capital companies are more socially responsible due to their higher extent of CSR. However, it is worth mentioning that, despite the fact that Lithuanian capital business entities still have a few outdated beliefs when it comes to CSR, the extent of social responsibility in these companies is not as low as one might expect and there is a rather clear tendency suggesting that CSR is becoming a significant part of business. According to it, it can be said that Lithuanian capital companies' views towards CSR are somewhere between modern and socioeconomic, while foreign capital companies mostly see CSR from a modern perspective and are a bit influenced by philanthropic factors. All things considered, despite of capital nature, business entities acknowledge all responsibilities and the only difference here is that foreign capital companies tend 
be more ethically responsible. To conclude, foreign capital business entities have a higher extent of social responsibility than Lithuanian capital business entities due to the fact that they are more experienced and developed in the field of CSR and have a clearer positioning when it comes to social responsibility.

\section{Conclusions and further research opportunities}

The analysis was conducted based on the improved two-dimensional CSR model, which included elements of the pyramid of CSR and the three-domain model, which gave a solid ground that allowed establishing differences among companies' social responsibility depending on their capital nature. The research revealed that Lithuanian capital business entities still tend to have more archaic beliefs, e.g., seeing CSR as a charitable activity or prioritizing profitability at any cost, meaning that they are a bit less socially responsible than foreign capital companies.

The inclusion of management types into the CSR valuation model was derived from the assumption that social responsibility of business is highly dependent on company's micro dimension, which determines the way a business entity is conducting its activities. The research exposed that although companies tend to grant priority to adhocratic management, the elements of other management types in companies are not equally important. The main disparity is that Lithuanian capital business entities give a higher priority to hierarchic and market types, while foreign capital companies prioritize clan type and at some level hierarchic management.

Finally, the research confirmed the fact that differently managed companies tend to be unevenly socially responsible. This conclusion is drawn because the similarities and differences of foreign and Lithuanian capital business entities' extent of CSR are reflected in similarities and differences of their management types.

In order to fully disclose this subject, it would be appropriate to present future research possibilities. First of all, although it was established that differences exist among the extent of CSR and predominant management types in companies, it still remains unclear what are the limits of Lithuanian capital business entities and their CSR, and why they fail to incorporate modern management practices. What is more, the research is mainly targeted at companies' micro dimension, therefore, it is thought that it is necessary to conduct a research and establish the minimal level of CSR in Lithuania. That in essence would allow assessing whether the minimal requirements of social responsibility are actually met in the country and if so, at what extent they are exceeded. Finally, in this research it was revealed that most of the researches in the field are limited by the fact that social irresponsible business entities are not interested in participating in them, therefore, their opinions are usually not taken into consideration, although they might be crucial in order to expose factors that restrict CSR, both in a particular country or region and in a socially irresponsible company itself. The same applies to the business entities which provide false data in order to create an image of socially responsible company. The method of data collection should be created, which would ensure that companies would have little to no chance of sabotaging the results by ignoring the research or providing false data. The methodology created during the latter research could also be used as a tool for further researches, in which the macro dimensions of other countries, e.g., European Union member states, could be measured. 


\section{References}

Aaronson, S.A. (2005). "Minding Our Business": What the United States Government Has Done and Can Do to Ensure that U.S. Multinationals Act Responsibly in Foreign Markets. Journal of Business Ethics. 59(1/2): 175-198.

Alas, R.; Ennulo, J., and Türnpuu, L. (2006). Managerial Values in the Institutional Context. Journal of Business Ethics. 65(3): 269-278.

Alas, R., and Rees, C. (2006). Work-related Attitudes, Values and Radical Change in Post-socialist Contexts: A Comparative Study. Journal of Business Ethics. 68(2): 181-189.

Alas, R., and Sun, W. (2008). Institutional Impact on Work Related Values in Chinese Organizations. Journal of Business Ethics. 83(2): 297-306.

Blowfield, M., and Frynas, J. (2005). Setting New Agendas: Critical Perspective on Corporate Social Responsibility in the Developing World. International Affairs. 81(3): 499-513.

Carroll, A.B.A. (1979). Three-dimensional Conceptual Model of Corporate Social Performance. Academy of Management Review. 4(4): 497-505.

Carroll, A.B. (1991). The Pyramid of Corporate Social Responsibility: Toward the Moral Management of Organizational Stakeholders. Business Horizons. 34(4): 39-48.

Carroll, A.B. (1999). Corporate Social Responsibility: Evolution of a Definitional Construct. Business \& Society. 38(3): 268-295.

Carroll, A.B., and Shabana, K.M. (2010). The Business Case for Corporate Social Responsibility: A Review of Concepts, Research and Practice. International Journal of Management Reviews. 12(1): 85-105.

Crane, A., and Matten, D. (2007). Business Ethics: Managing Corporate Citizenship and Sustainability in the Age of Globalization. 2nd ed. New York: Oxford University Press.

Davis, J.H., and Ruhe, J.A. (2003). Perception of Country Corruption: Antecedents and Outcomes. Journal of Business Ethics. 43(4): 275-288.

European Commission. (2011). Communication from the Commission to the European Parliament, the Council, the European Economic and Social Committee and the Committee of the Regions. A renewed EU strategy 2011-14 for Corporate Social Responsibility. Retrieved December 2, 2013 from http://eur-lex.europa.eu/LexUriServ/LexUriServ.do?uri=COM:2011:0681:FIN:EN:PDF

Lantos, G.P. (2001). The Boundaries of Strategic Corporate Social Responsibility. Journal of Consumer Marketing. 18(7): 595-630.

Mačys, G., and Vijeikis, J. (2010). Does the Social Relationship Matter? The Corporate Social Responsibility. African Journal of Political Science and International Relations. 4(8): 308-318.

Marinetto, M. (1999). The History Development of Business Philanthropy: Social Responsibility in the New Corporate Economy. Business History. 41(4): 1-20.

Matten, D., and Moon, J. (2008). "Implicit" and "Explicit" CSR: A Conceptual Framework for a Comparative Understanding of Corporate Social Responsibility. Academy of Management Review. 33(2): 404-424.

Mintzberg, H. (1983). The Case for Corporate Social Responsibility. Journal of Business Strategy. 4(2): 3-15.

Mueller, K.; Hattrup, K.; Spiess, S.O., and Lin-Hi, N. (2012). The Effects of Corporate Social Responsibility on Employees' Affective Commitment: A Cross-cultural Investigation. Journal of Applied Psychology. 97(6): 1186-1200.

EuroVoc. (2013). Corporate Social Responsibility. Retrieved on December 2, 2013 from http:// eurovoc.europa.eu/drupal/?q=request $\&$ view=pt\&termuri=http://eurovoc.europa. eu/216606\&language $=$ en

Quazi, A.M., and O'Brien, D. (2000). An Empirical Test of a Cross-national Model of Corporate Social Responsibility. Journal of Business Ethics. 25(1): 33-51.

Government of the Republic of Lithuania. (2010). Resolution on National corporate social responsibility development program in 2009-2013 and action plan on measures promoting corporate social responsibility in Lithuania in 2009-2011. Retrieved on December 2, 2013 from http://www3.Irs. lt/pls/inter3/dokpaieska.showdoc_l?p_id=432243\&p_query $=\&$ p_tr2 $=2$ 
Schwartz, M.S., and Carroll, A.B. (2003). Corporate Social Responsibility: A Three-domain Approach. Business Ethics Quarterly. 13(4): 503-530.

Taras, V.; Steel, P., and Kirkman, B.L. (2011). Three Decades of Research on National Culture in the Workplace: Do the Differences Still Make a Difference? Organizational Dynamics. 40(3): 189198.

Ubius, U., and Alas, R. (2009). Organizational Culture Types as Predictors of Corporate Social Responsibility. Engineering Economics. 61(1): 90-99.

Unerman, J., and O'Dwyer, B. (2006). Theorizing Accountability for NGO Advocacy. Accounting, Auditing and Accountability Journal. 19(3): 349-376.

Vilkè, R. (2011). Corporate Social Responsibility Implementation Effectiveness Improvement in Lithuania: Model of Local Government Involvement. Vilnius: Mykolas Romeris University.

Žitkus, L., and Junevičius, A. (2007). Boundaries of Possible Solutions of Management Problems Caused by Cultural Interaction. Engineering Economics. 51(1): 44-49.

Waddoc, S. (2004). Companies, Academics and the Progress of Corporate Citizenship. Business and Society Review. 109(1): 5-42.

\title{
UŽSIENIO IR LIETUVOS KAPITALO KOMPANIJŲ SOCIALINE் ATSAKOMYBE்
}

\author{
Alfonsas LAURINAVIČIUS \\ Mykolo Romerio universitetas, Lietuva \\ Martynas VAIČIULIS \\ Mykolo Romerio universitetas, Lietuva
}

Santrauka. Straipsnis orientuotas ị užsienio ir Lietuvos kapitalo verslo subjektus, registruotus Lietuvos Respublikoje, ir skirtumus tarp jų socialinio atsakingumo bei juose vyraujančių vadybos tipų. Tyrimas šiame straipsnyje remiasi Lietuvoje vyraujančiu labiau teigiamu požiūriu, nukreiptu ị užsienio kapitalo verslo subjektus dẻl jų potencialiai aukštesnio socialinès atsakomybès lygio, bei šios prielaidos pagrịstumo trūkumu.

Tyrimu nustatyta, jog skirtumai tarp kompanijų egzistuoja, tačiau jie nèra tokie drastiški, kaip yra teigiama. Išsiaiškinta, jog Lietuvos kapitalo verslo subjektams vis dar stinga pakankamai išvystyto ISA suvokimo, o tai reiškia, jog jų socialinès atsakomybès lygis yra kiek menkesnis nei užsienio kapitalo kompanijų, nes šalyje İSA idejja yra santykinai nauja. Vis dèlto, yra pastebima teigiama tendencija, leidžianti teigti, jog i̇monių socialinė atsakomybė palaipsniui igauna vis daugiau svarbos Lietuvos verslo pasaulyje.

Reikšminiai žodžiai: įmonių socialinė atsakomybė (I̦SA), vadybos tipas, užsienio kapitalas, Lietuvos kapitalas, konceptualus modelis. 